Bazyli CZECZUGA

Biochemistry

\title{
CAROTENOIDS IN FISH XXXIV. CAROTENOIDS \\ IN UNEVEN AGED INDIVIDUALS \\ OF CERTAIN ANTARCTIC SPECIES OF FISH
}

\section{KAROTENOIDY U RYB. XXXIV. KAROTENOIDY U ROOZZNYCHWIEROWO OSOBNIKÓW NIEKTORRYCH GATUNKÓW RYB Z ANTARKTYDY}

\author{
Department of General Biology \\ Białystok Medical Academy, 15-230 Białystok, Poland
}

\begin{abstract}
By means of columnar and thin-layer chromatography, the author investigated the presence of various carotenoids in six fish species from the Antarctic (Dissositichus eleginoides, Notothenia gibberifrons, Pseudochaenichtys georgianus, Trematomus hansoni, Trematomus bernacchii and Bathydraco macrolepis).

The presence of the 20 carotenoids has been found.

The total content of carotenoids ranged from 0.011 (Notothenia gibberifrons, $35.0 \mathrm{~cm}$ body length to $1.291 \mu \mathrm{g} / \mathrm{g}$ wet weight (fins of Bathydraco macrolepis).
\end{abstract}

\section{INTRODUCTION}

Our previous studies on the occurrence of carotenoids in fish dealt mainly with the presence of various carotenoids in different parts of the body of several fish species, both freshwater and marine (Czeczuga 1973, 1975). Attention was also paid to the effect of different types of food on the occurrence and the total content of carotenoids in the 
various parts of the fish body; the significance of natural and.artificial food was in studied on Salmo trutta (Czeczuga 1979 a) whereas effect of parasites or pollution of the habitat were investigated in the case and the carp (Czeczuga $1979 \mathrm{~b}$ ). Whilst carrying out investigations on carotenoids in Antartic fish species (Czeczuga and Kłyszejko 1978), we felt that studies on the presence and amounts of carotenoids in individuals of various age, belonging to economically significant species in that region would be of interest since these species providing, as they do a source of animal protein are now being caught in increasing numbers by fishing fleets from various countries of the world.

\section{MATERIAL AND METHODS}

The material were brought to the laboratory in deep-freeze containers $\left(-20^{\circ} \mathrm{C}\right)$ after being caught during the 8sh cruise of RV "Profesor. Siedlecki" in 1978. The material, thus obtained comprised the following fish species: Dissostichus eleginoides, Notothenia gibberifrons, Pseudochaenichthys georgianus, Trematomus hansoni, Trematomus bernacchii and Bathydraco macrolepis. For analysis of the carotenoid content assays 30-32 g samples of the flesh from the middle part of the body were removed from each individual of the species under study. A sample consisting of muscular tissue together with the skin from the same part of the body was also studied. These samples were taken from all the fishes, from the youngest to the oldest individual of a given species. Such a sampling method was dictated by the assumption of expressed by Shust and Pinskaya (1978) that the inear growth of Antarctic fishes was a manifestation of their age. The brain and fins, sk:n and muscles of each species were analysed.

The material were prepared immediately on collection by placing them into dark giass containers and covering them with $96 \%$ acetone. They were kept in a refrigerator until the spectrophotometric determinations were made.

The carotenoid pigments were extracted by means of $96 \%$ acetone in a dark room. Saponification was carried out by means of $10 \% \mathrm{KOH}$ in ethanol at about $20^{\circ} \mathrm{C}$ for 24 for hours in the dark in a nitrogen atmosphere.

Columnar and thin-layer chromatography, described in detail in our previous papers (Czeczuga and Czerpak 1976) were used for the separation of the various carotenoids. A glass column (Quickfit-England), approximately $1 \mathrm{~cm}$ dia. and $15-20 \mathrm{~cm}$ long, filled with $\mathrm{Al}_{2} \mathrm{O}_{3}$, was used in column chromatography. The extract was passed through the column after which the different fractions were eluted with the solvent. Silica gel was used for the thin-layer chromatography, with the appropriate solvent systems, the $R_{f}$ values being determined for each spot.

The pigments were identified by the following methods: a) behaviour on column chromatography; b) absorption spectra of the pigments in various solvents were recorded by a Beckman model 2400 DU spectrophotometer; c) the partition characteristic of the carotenoid between hexane and $95 \%$ methanol; d) comparison of $\mathbb{R}_{\mathrm{f}}$ on thin-layer chromatography; for identification of $\beta$-carotene, canthaxanthin, lutein, zeaxanthin, and 
astaxanthin co-chromatography was applied using identical carotenoids (manufactured by Hoffmann-La Roche and Co. Ltd., Basle, Switzerland and Sigma Chemical Company, USA); e) the presence of allylic hydroxyl groups was determined with acid chloroform; and $f$ ) the epoxide test.

Quantitative determinations of carotenoid concentrations were made the quantitative absorption spectra. These determinations were based on the extinction coefficient $\mathrm{E} 1 \% / \mathrm{cm}$ at maximum absorbance wavellength in petroleum ether or hexane.

\section{RESULTS}

The carotenoids found to be present in the Dissostichus eleginoides individuals investigated are shown in Table 1, from which it will be seen that 11 carotenoids were identified in this material. The commonest carotenoids were zeaxanthin and asthaxanthin. The presence of $\alpha$-doradexanthin and phoenicoxanthin in worth mentioning. The analysis of carotenoid contents in individuals of different body lengths (Table 2) revealed that up to $49.0 \mathrm{~cm}$ body length the total carotenoid content increased with fish growth, after which a slight fall was observed. Different fish growth groups showed the domination of various carotenoids. It is of interest that the total carotenoid content was higher in the brain of this species than in the muscles (Table 7).

The carotenoids and range of their percentages in the Notothenia gibberifrons individuals are presented in Table 3. Thirteen carotenoids were identified, of which the most noteworthy of which were $\alpha$-cryptoxanthin and tunaxanthin. In the specimens of

Table 1

Carotenoid content in the body of the Dissostichus eleginoides

\begin{tabular}{|l|c|}
\hline \multicolumn{1}{|c|}{ Carotenoid } & fluctuations in $\%$ \\
\hline$\beta$ - carotene epoxide & 18.8 \\
$\beta$-cryptoxanthin & 29.0 \\
lutein (free and epoxide) & $10.0-16.5$ \\
zeaxanthin & $21.3-39.2$ \\
phoenicoxanthin & 28.6 \\
$\alpha$-doradexanthin & $17.5-28.1$ \\
astaxanthin & $13.7-40.5$ \\
astaxanthin ester & $10.7-15.0$ \\
aurochrome & $7.2-18.5$ \\
mutatochrome & $7.0-34.8$ \\
mutatoxanthin & $6.4-7.8$ \\
\hline
\end{tabular}


Carotenoid content in the Dissostichus eleginoides and different body lengths

\begin{tabular}{|c|c|c|}
\hline $\begin{array}{l}\text { length of } \\
\text { body in } \mathrm{cm}\end{array}$ & $\begin{array}{c}\text { total } \\
\text { content of } \\
\text { carotenoids } \\
\text { in } \mu \mathrm{g} / \mathrm{g} \text { f.w. }\end{array}$ & dominating carotenoids \\
\hline 28.5 & 0.043 & astaxanthin $(21.8 \%)$, zeaxanthin $(23.3 \%)$ \\
\hline 35.0 & 0.077 & $\begin{array}{r}\text { zeaxanthin }(39.2 \%), \beta \text {-cryptoxanthin } \\
(30.6 \%)\end{array}$ \\
\hline 49.0 & 0.083 & $\begin{array}{r}\beta \text {-cryptoxanthin (29.0\%), astaxanthin } \\
(18.0 \%)\end{array}$ \\
\hline 60.0 & 0.080 & $\begin{array}{l}\text { zeaxanthin }(35.1 \%), \alpha \text {-doradexanthin } \\
\qquad(28.1 \%)\end{array}$ \\
\hline 68.0 & 0.077 & mutatochrome $(34.8 \%)$, zeaxanthin $(24.6 \%)$ \\
\hline
\end{tabular}

Carotenoid content in the body of the Notothenia gibberifrons

\begin{tabular}{|l|c|}
\hline \multicolumn{1}{|c|}{ Carotenoid } & fluctuations in $\%$ \\
\hline$\beta$-carotene & $9.6-15.7$ \\
$\beta$-carotene epoxide & $9.9-36.6$ \\
$\alpha$-cryptoxanthin & $5.3-5.6$ \\
$\beta$-cryptoxanthin & $8.2-19.3$ \\
canthaxanthin & $3.1-18.2$ \\
lutein (free and epoxide) & $5.8-25.7$ \\
zeaxanthin & $6.1-39.3$ \\
phoenicoxanthin & 22.9 \\
tunaxanthin & 19.0 \\
astaxanthin & $5.2-33.8$ \\
astaxanthin ester & $7.6-17.4$ \\
aurochrome & 60.7 \\
mutatochrome & $3.2-43.4$ \\
\hline
\end{tabular}

different lengths the total carotenoid content was found to rise in the fishes of $35 \mathrm{~cm}$ to $50 \mathrm{~cm}$ (Table 4). While the smaller specimens contained $0.011 \mu \mathrm{g} / \mathrm{g}$ on the average, the specimens $50 \mathrm{~cm}$ length contained $0.283 \mu \mathrm{g} / \mathrm{g}$ body weight. In the brain of the individuals studied, zeaxanthin and astaxanthin predominated and the total carotenoid content was $0.262 \mu \mathrm{g} / \mathrm{g}$.

The results of the analyses for Pseudochaenichthys georgianus are shown in Table 5, which gives the carotenoids determined and percentage ranges. Fourteen carotenoids were 
Carotenoid content in the Notothenia gibberifrons and different body lengths

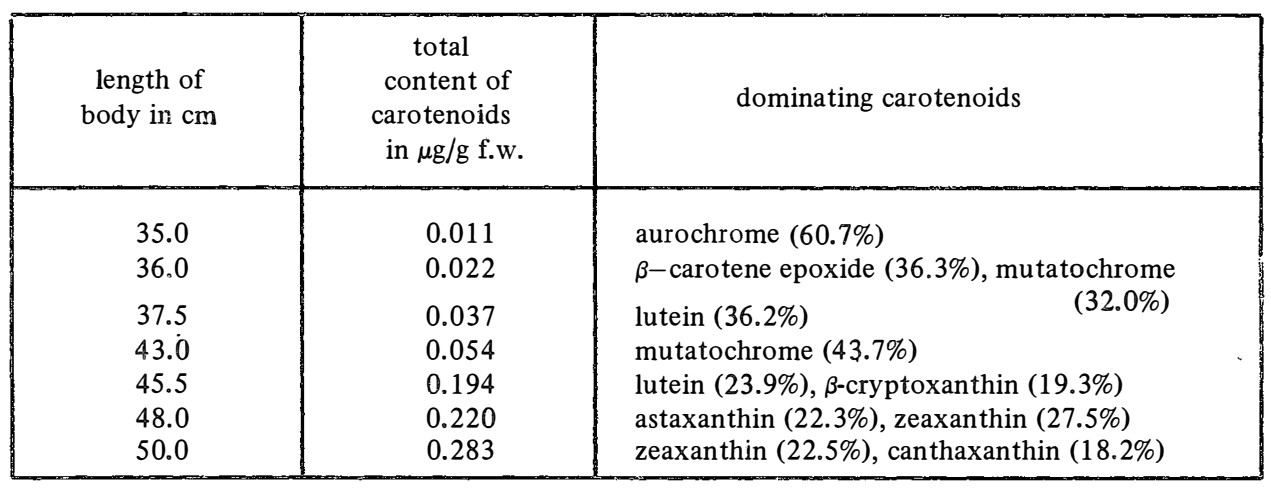

Table 5

Carotenoid content in the body of the Pseudochaenichthys georgianus

\begin{tabular}{|l|c|}
\hline \multicolumn{1}{|c|}{ Carotenoid } & fluctuations in $\%$ \\
\hline$\beta$-carotene & $8.2-12.6$ \\
$\beta$-carotene epoxide & 12.3 \\
$\beta$-cryptoxanthin & $16.5-46.5$ \\
canthaxanthin & $4.2-21.7$ \\
lutein (free and epoxide) & $4.0-37.2$ \\
zeaxanthin & $22.8-47.8$ \\
phoenicoxanthin & $10.3-23.8$ \\
neothxanthin & 9.6 \\
astaxanthin & $8.3-18.8$ \\
astaxanthin ester & $2.6-29.2$ \\
aurochrome & $11.5-12.7$ \\
auroxanthin & 13.2 \\
mutatochrome & $8.6-24.3$ \\
mutatoxanthin & $7.7-11.6$ \\
\hline
\end{tabular}

Table 6

Carotenoid content in the Pseudochaenichthys georgianus and different body lengths

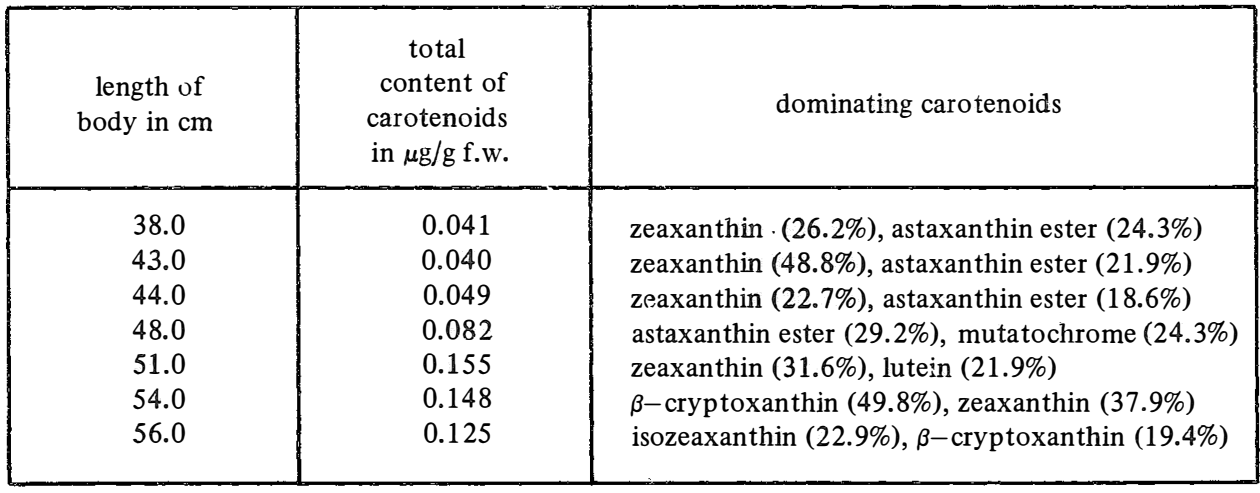


Carotenoid content in the brain of some fish (in \%)

\begin{tabular}{|l|c|c|c|}
\hline \multicolumn{1}{|c|}{ Carotenoid } & D. eleginoides & N. gibberifrons & P. georgianus \\
\hline p-cryptoxanthin & & & 21.7 \\
canthaxanthin & & & 9.2 \\
lutein & & 5.8 & 37.6 \\
phoenicoxanthin & 28.6 & 33.9 & 23.8 \\
zeaxanthin & 11.1 & 33.8 & \\
astaxanthin & 37.5 & 17.4 & 7.7 \\
astaxanthin ester & 15.0 & 9.1 & \\
mutatoxanthin & 7.8 & & \\
\hline Total content of & & 0.262 & 0.214 \\
carotenoids in & 0.138 & & \\
$\mu$ g/g fresh weight & & & \\
\hline
\end{tabular}

Table 8

Carotenoid content in the body of the Trematomus hansoni

\begin{tabular}{|l|c|}
\hline \multicolumn{1}{|c|}{ Carotenoid } & fluctuations in \% \\
\hline$\alpha$-carotrne & $5.9-29.1$ \\
$\beta$-carotıne & $7.9-13.4$ \\
$\alpha$-cryptoxanthin & 18.2 \\
$\beta$-cryptoxanthin & $8.1-9.4$ \\
$\beta$-carotene epoxide & 11.2 \\
lutein & $11.7-18.8$ \\
zeaxanthin & $11.2-55.2$ \\
canthaxanthin & 15.7 \\
astaxanthin & $6.7-19.9$ \\
astaxanthin ester & 23.1 \\
aurochrome & 14.2 \\
mutatochrome & $7.4-21.1$ \\
mutatoxanthin & 8.9 \\
\hline
\end{tabular}

Table 9

Carotenoid content in the Trematomus hansoni and different body lengths

\begin{tabular}{|c|c|c|}
\hline $\begin{array}{l}\text { length of } \\
\text { body in } \mathrm{cm}\end{array}$ & $\begin{array}{c}\text { total } \\
\text { content of } \\
\text { carotenoids } \\
\text { in } \mu \mathrm{g} / \mathrm{g} \text { f.w. }\end{array}$ & dominating carotenoids \\
\hline $\begin{array}{l}31-33 \\
41-42\end{array}$ & $\begin{array}{l}0.043 \\
0.069\end{array}$ & $\begin{array}{l}\alpha \text {-carotene }(19.1 \%), \beta \text {-carotene }(19.0 \%), \\
\text { zeaxanthin }(55.2 \%) \\
\text { zeaxanthin }(32.9 \%), \text { astaxanthin ester }(23.1 \%)\end{array}$ \\
\hline
\end{tabular}


identified, the most noteworthy being the $\epsilon$-carotene derivative, neothxanthin. The commonest carotenoids in this species were $\beta$-cryptoxanthin, zeaxanthin and astaxanthin. The studies on the total carotenoids content in individuals of various lengths (Table 6) revealed the content to rise, beginning with the smallest specimens up to those $51 \mathrm{~cm}$ long, past which a tendency to fall was observed. The dominant carotenoids were, in most cases zeaxanthin and astaxanthin. The brain carotenoid was higher than that of the muscles even in those specimens found to contain the largest amount of carotenoids.

Two growth classes of Trematomus hansoni were also studied for their carotenoid content. The carotenoids are listed in Table 8 and their total amount found in individuals from different growth groups are shown in Table 9. It should be noted that $\alpha$-carotene was present in this species. The commonest carotenoid was zeaxanthin.

Table 10

Carotenoid content in the body of the Trematomus bernacchii (in \%)

\begin{tabular}{|l|r|}
\hline \multicolumn{1}{|c|}{ Carotenoid } & $\%$ \\
\hline$\alpha$-carotene & 9.3 \\
$\beta$-cryptoxanthin & 9.4 \\
lutein & 12.3 \\
tunaxanthin & 7.1 \\
zeaxanthin & 14.8 \\
astaxanthin & 28.9 \\
aurochrome & 5.0 \\
\hline Total content of carotenoids & 0.142 \\
\hline in $\mu \mathrm{g} / \mathrm{g}$ fresh weight & \\
\hline
\end{tabular}

Table 11

Carotenoid content in some parts of the body of the Bathydraco macrolepis (in \%)

\begin{tabular}{|l|r|r|r|}
\hline \multicolumn{1}{|c|}{ Carotenoid } & fins & skin & muscles \\
\hline$\beta$-carotene epoxide & & 10.9 & \\
$\beta$-cryptoxanthin & 10.1 & 15.6 & 34.7 \\
$\alpha$-doradexanthin & 12.4 & & 3.8 \\
canthaxanthin & 6.5 & & 25.4 \\
lutein (free and epoxide) & 21.3 & 46.3 & 8.0 \\
isolutein & 28.5 & 27.2 & 5.3 \\
zeaxanthin & 21.2 & & 16.5 \\
astaxanthin & & & 6.3 \\
astaxanthin ester & & & \\
mutatoxanthin & 1.291 & 1.272 & 0.138 \\
\hline Total content of carotenoids & & & \\
in $\mu$ g/g fresh weight & & & \\
\hline
\end{tabular}


The presence of these pigments was also investigated in one specimen of the Trematomus bernacchii (Table 10) and Bathydraco macrolepis (Table 11), the species yielding a single individual each. The most interesting finding was the presence of $\alpha$-carotene in the Trematomus bernacchii individual and isolutein in the Bathydraco macrolepis one.

\section{DISCUSSIOP}

The results of these studies show that the list of carotenoids found to date in fish of the Antarctic (Czeczuga and Kłyszejko 1978) should be extended to include $\alpha$-carotene, $\beta$-cryptoxanthin, phoenicoxanthin, $\alpha$-doradexanthin, neothxanthin and isolutein. Neothxanthin is a derivative of $\epsilon$-carotene (3-hydroxy- $\epsilon$-carotene) which lies in the conversion pathway of $\epsilon$-carotene to tunaxanthin. This carotenoid was first reported to be present in fish by Tanaka et al. (1977), who found it in marine species, Neothunnus albacora. The present author (1980) noted its presence in some species, representatives of the family Pleuronectidae, from the Baltic Sea. As noted in a previous paper (Czeczuga $1979 \mathrm{~b}$ ), grows the total carotenoid content of Cyprinus carpio increases with fish growth since a number of carotenoids are accumulated in the various parts of the body. On the whole this has been confirmed in the present study on Antarctic fishes particularly as regards Notothenia gibberifrons. On he other hand, it was found that in two other species, the increase in carotenoid content occured at a definite age past which a tendency to decline was observed. This may be related to changes in the dietary spectrum of these fish as they grow older. Previous studies on the Notothenia gibberifrons (Shust and Pinskaya 1978) have shown that these fishes permanently inhabit the sea bottom and feed mainly on benthos. The alimentary canal of the individuals of this species were filled in 75\% with Polychaeta fragmented crustaceans, representatives of the Echinodermat and molluscs. Krill, however, is found far less frequently in the alimentary canal of this species than in other representatives of this family. In two other species in which growth - related changes in the carotenoid content were studied the dietary spectrum underwent changes. Particularly in the adult Pseudochaenichthys georgianus, a large proportion of the alimentary canal content consitend of krill; schools of these fish searching for food are often observed (Permitin, 1969; Permitin and Tarverdieva, 1972; Permitin and Sazanov, 1974; Tarverdieva, 1972).

It was of interest to note that the brain tissue of some of the fish species under study contained comparatively large amounts of carotenoids. This would confirm our previous observations concerning the quite high carotenoid concentrations in the brain of certain freshwater fish (Czeczuga 1977), especially those inhabiting waters not very rich in oxygen (thunder fish).

Considering the carotenoids found in the fish species studied here, one is tempted to suggest the astaxanthin synthesis pathway in these fishes. The biosynthesis of astaxanthin is likely to occurs by way of $\beta$-carotene conversion into echinenone which is then 
converted into canthaxanthin; this is then converted into phoenicoxanthin which is, in turn, converted into astaxanthin. Though echinenone has not been found in fishes of the Anctarctic, yet it has nevertheless been found quite often in other fish species both freshwater (Czeczuga 1979 a,b) and marine (Tanaka, 1978). The conversion described form probably one of the fundamental pathway of astaxanthin biosyntesis in fish.

\section{REFERENCES}

Czeczuga B., 1973. Carotenoids in fish. II. Carotenoids and Vitamin A in some fishes from the coastal region of the Black sea. - Hydrobiologia 41:113-125.

Czeczuga B., 1975. Carotenoids in fỉsh. IV. Salmonidae and Thymallidae from Polish waters. Hydrobiologia 46: 223-239.

Cżeczuga B., 1.977. Carotenoids in fish. XVIII. Carotenoids in the brain of some fishes. - Folia Histochem. et Cytochem. 15: 343-346.

Czeczuga B., 1979 a. Carotenoids in fish. XX. Carotenoids in Salmo gairdneri Rick. and Salmo trutta morpha fario L. - Hydrobiologia, 63: 15-23.

Czeczuga B., 1979 b. Carotenoids in fish. XXII. Changes of carotenoids in Cyprinus carpio L. Hydrobiologia, 64: 233-240.

Czeczuga B., 1980. Carotenoids in fish. XXVII. Pleuronectidae from Baltic sea. - Acta Ichthyol. Piscat., X, 1: 119-126.

Czeczuga B. and Czerpak R., 1976. Carotenoids in fish. VII. The kind of food and the content of carotenoids and Vitamin A in Carassius carassius (L.) and Leucaspius delineatus (Heck.). - Acta Hydrobiol., 18: 1-21.

Czeczuga $\mathbb{B}$. and Kłyszejko, B., 1978. Carotenoids in fish. XIV. The carotenoid content in the flesh of certain species from the Antarctic. - Hydrobiologia, 60: 173-175.

Permitin Yu.E., 1969. New data on the specific composition and distribution of fish in the Scotia Sea. - Problems of Ichthology 9: 221-239.

Permitin Yu.E. and Sazanov, Yu.I., 1974. Taxonomy Notothenia squamifrons Günther and related species. Problems of Ichthology 14: 589-601.

Permitin Yu.E. and Tarverdieva M.I., 1972. The feeding of some Antartic species of antarctic fishes in the South Georgia area. Problems of İchthology 12: 120-132.

Shust K.V., Pinskaya, I.A., 1978. Age and growth of the six species of notothenioid fishes (fam. Nototheniidae). Problems of Ichthology 18: 837-843.

Tanaka Y., 1978. Comparative biochemical studies on carotenoids in aquatic animals. - Mem, Fac. Fish. Kagoshima Univ., 27: 355-422.

Tanaka Y., Shimamura, F. and Katayama, T., 1977. The existence of 3-hydroxy-e-carotene (neothxanthin) in kiwada, Neothunnus albacora. - Mem. Fac. Fish., Kagoshima Univ., 26: 33-37.

Tarverdieva M.I., 1972. The daily diet and the feeding pattern of marbled notothenia (Notothenia rossi marmorata) and Patagomian toothfish Dissostichus eleginoides (Family Nototheniidae) in the South Georgia area. - Problems of Ichthology 12: 748-756.

Translated: Dr Teresa Radziejewska 
B. Czeczuga

\section{KAROTENOIDY U RYB. XXXIV. \\ KAROTENOIDY U RÓZ̊NYCH WIEKOWO OSOBNIKÓW NIEKTÓRYCH GATUNKÓW RYB Z ANTARKTYDY}

\section{Streszczenie}

Autor stosując chromatografię kolumnową i cienkowarstwową badał zawartość poszczególnych karotenoidów w mięśniach różnych wiekowo sześciu gatunków ryb z wód Antarktydy.

W wyniku badań ustalono obecność takich karotenoidów jak: $\alpha$-, $\beta$-carotene, $\beta$-carotene epoxide, $\alpha$-, $\beta$-cryptoxanthin, cantaxthin lutein, lutein epoxide, isolutein, zeaxanthin, neothxanthin, astaxanthin, astaxanthin ester, mutatochrome, mutatoxanthin, aurochrome oraz auroxanthin.

Podano również wahania procentowe poszczególnych karotenoidów oraz ogólną ich zawartość dla badanych gatunków ryb. Okazało się, że mięśnie osobników niektórych gatunków ryb najzasobniejsze są w karotenoidy w wieku najstarszym (Notothenia gibberifron, Trematomus hansoni) osobniki zaś pozostałych gatunków, najwięcej zawierają karotenoidów w wieku dojrzałym (średnim).

\section{5. पе чуга}

\section{КАРОТИНОИДЫ У РЫБ. ХХХІУ. КАРОТИНОИДЫ У РАЗЛИЧНЫХ ПО ВОЗРАСТУ ОСОБЕИ НЕКОТОРЫХ ВИДОВ РЫБ АНТАРКТИКИ}

$$
\text { P e } 3 \text { in M e }
$$

Применяя колонную и тонкослойную хроматографию автор исследовал содержание отдельных каротиноидов в мясе различающихся возрастом 6-ти видов рыб Антарктики.

цоказали наличие таких каротиноидов как: $\alpha$ - $\beta$-carotene $\beta$-carotene epoxide, $\alpha-, \beta$ - oryptoxanthin, cantaxthin, lutein, lutein epoxide, isolutein, zeaxanthin, neothxanthin, astaxanthin, astaxanthin ester, mutatochro me, mutatoxanthin, aurochrome, auroxantin.

Приводятся также процентные колебания отдельных каротиноидов, а также их общее содержание для исследованных видов рыб. Обнаружили, что мышш некоторых видов рыб являются богатыми содержанием каротиноидов в самом старшем возрасте (Notothenia gibberifrons, Trematomus hansoni ), особи других видов содержат наибольшее количество каротиноидов в зрелом(среднем) возрасте.

Перевод: dr Józef Domagała

Received: 20 VI $1981 \mathrm{r}$.

Address:

Prof.dr hab. Bazyli Czeczuga

Zakład Biologii Ogólnej

Akademii Medycznej

15-238 Białystok

Polska - Fol and 